\title{
ACRL Candidates, 1984 Elections
}

The listing for each of the following candidates includes the title, institution, and institutional address.

\section{Vice-President/President-Elect}

Sharon A. Hogan, Deputy Director, Temple University Libraries, 13th \& Berks Mall, Philadelphia, PA 19122; Janice T. Koyama, Head, Moffitt Undergraduate Library, University of California, Berkeley, Berkeley, CA 94720.

\section{Anthropology and Sociology Section (ANSS)}

Vice-Chair/Chair-Elect: Jean Shaw Adelman, Librarian, University Museum, University of Pennsylvania, Philadelphia, PA 19104; Lynne M. Schmelz-Keil, Head of Public Services, Dana Library, Rutgers University, New Brunswick, NJ 08901.

Member-at-Large (two-year term): Chris D. Ferguson, Social Sciences Bibliographer, University Library, University of California, Irvine, CA 92713; Cheryl C. Kugler, 819 Neartop Drive, Nashville, TN 37205; Ann L. Wood, Reference Librarian, Goodell Library, University of Massachusetts, Amherst, MA 01002.

\section{Art Section (ARTS)}

Vice-Chair/Chair-Elect: Darryl Barrett, Art Reference Librarian, Minneapolis Public Library, 300 Nicollet Mall, Minneapolis, MN 55401; James H. Carmin, Reference Librarian, Architecture and Allied Arts Library, University of Oregon, Eugene, OR 97403.

\section{Asian and African Section (AAS)}

Vice-Chair/Chair-Elect: Thomas H. Lee, East Asian Languages Cataloging Team, University of Wisconsin Memorial Library, 728 State Street, Madison, WI 53706; Margaret K. Wang, Serials Catalog Librarian, University of Delaware Library, Newark, DE 19711.

Member-at-Large (three-year term): Katharine K. Elsasser, Senior Subject Cataloging Specialist, Library of Congress, Washington, DC 20540; Cecelia L. Shores, Head, Acquisitions Department, The Center for Research Libraries, 6050 S. Kenwood, Chicago, IL 60637.

\section{Bibliographic Instruction Section (BIS)}

Vice-Chair/Chair-Elect: Mary Reichel, Head, Reference Department, Pullen Library, Georgia State University, 100 Decatur Street, S.E., Atlanta, GA 30303; Virginia Tiefel, Head, Undergraduate Libraries and Director of Library User Education, Ohio State University, 1858 Neil Avenue Mall, Columbus, OH 43210.

Secretary (one-year term): Betsy Baker, Acting Bibliographic Instruction Services Librarian,
Northwestern University Library, 1935 Sheridan Road, Evanston, IL 60201; Ellen Meltzer, Assistant to the Associate University Librarian for Public Service, 245 Doe Library, University of California, Berkeley, CA 94720.

Member-at-Large (three-year term): Carolyn Dusenbury, Head of Reference Service, 110 Hayden Library, Arizona State University, Tempe, AZ 85287; Jacquelyn Morris, Associate Director and Professor of Libraries, University of the Pacific, Stockton, CA 95211.

\section{College Libraries Section (CLS)}

Vice-Chair/Chair-Elect: Jean C. Pelletière, Director, Union College Libraries, Schenectady, NY 12308; Joan Stockard, Reader Services Librarian, Wellesley College Library, Wellesley, MA 02181.

Secretary (one-year term): Frances Cable, Associate Librarian, Reference Department, Pennsylvania State University Libraries, University Park, PA 16802; Janet Sheets, Reference Librarian, Baylor University, P.O. Box 6307, Waco, TX 76798.

\section{Community and Junior College Libraries SeCtion (CJCLS)}

Vice-Chair/Chair-Elect: James F. McCoy, Di-

\section{VIRGO TO LEAVE ACRL}

Julie Carroll Virgo, executive director of ACRL since 1977, has submitted her resignation effective June 30,1984 . She has accepted a position as vicepresident of the Carroll Group, a management consulting firm. She will also remain on the faculty of the University of Chicago's Graduate Library School.

In her role as ACRL's executive officer, she has given excellent direction to the ACRL Headquarters office and has offered invaluable counsel to ACRL's leaders.

A native of Australia,

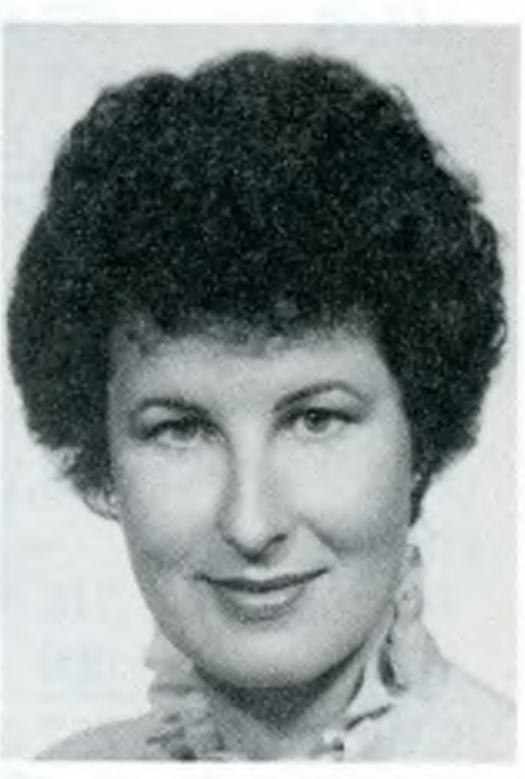

Julie Virgo Virgo came to the United States in 1966 where she obtained an MLS (1968), a Ph.D. in librarianship (1974), and an MBA (1983) from the University of Chicago. Before coming to ACRL she served as director of education for the Medical Library Association.

Dr. Virgo's resignation represents a significant loss for ACRL and ALA-she leaves, however, with best wishes from all of us.-Joyce Ball, ACRL President. 


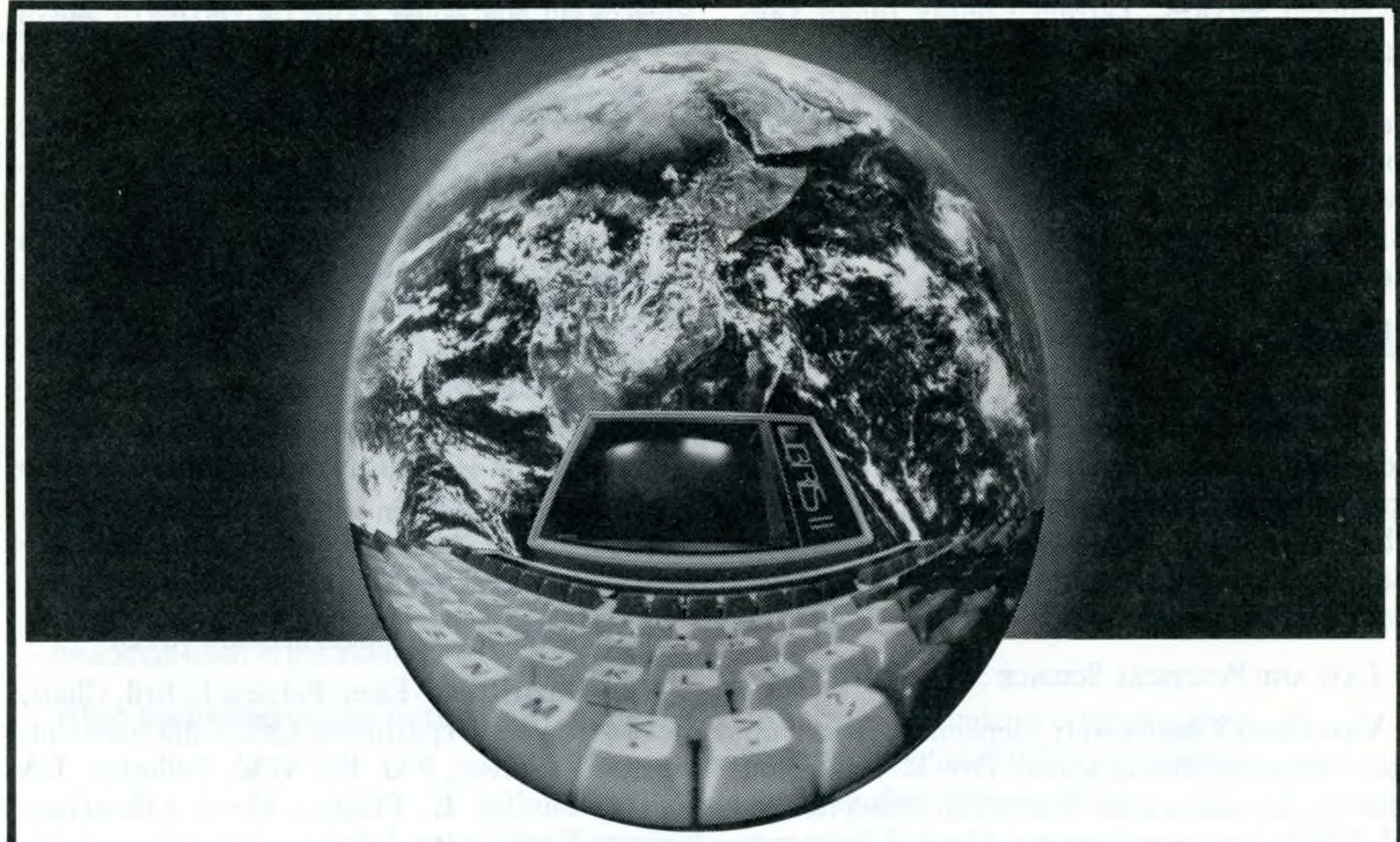

\section{YOU'LLADVANCE CONFIDENTLY IN THE WORLD OF TECHNOLOGY}

\section{WHEN YOUR ON-LINE SYSTEM IS BASED ON LIBRARY KNOWLEDGE}

Baker \& Taylor's LIBRIS II On-Line Acquisitions System represents state-of-the-art technology coupled with 155 years of library experience.

Only Baker \& Taylor can offer a complete acquisitions system featuring:

- electronic ordering from the nation's largest stock of books

- a 700,000+ title database

- automated open-order control

- automated fund accounting

For details, contact the Sales Department of the division nearest you. LIBRIS II, only from Baker \& Taylor.

EASTERN , 50 Kirby Avenue, Somerville, NJ 08876, (201) 722-8000

MIDWESTERN, 501 S. Gladiolus Street, Momence, IL 60954, (815) 472-2444

SOUTHERN , Mt. Olive Road, Commerce, GA 30599, (404) 335-5000

WESTERN , 380 Edison Way, Reno, NV 89564. (702) 786-6700 
rector of Learning Resources, Hudson Valley Community College, 80 Vandenburgh Avenue, Troy, NY 12180; Kay M. Stansbery, Director of Technical Services, Tarrant County Junior College, 828 Harwood Road, Hurst, TX 76053.

Secretary (one-year term): Ilona G. Grack, Head Librarian, Jefferson Community College/ Southwest, 1000 Community College Drive, Louisville, KY 40272; Joseph Rine, Head Librarian, Minneapolis Community College Library, 1501 Hennepin, Minneapolis, MN 55403.

\section{Education and Behavioral Sciences Section} (EBSS)

Vice-Chair/Chair-Elect: AdeleS. Dendy, Head, Education Library, Indiana University Library, 3rd \& Jordan Streets, Bloomington, IN 47405; Charles Thurston, Education Reference Librarian, John Peace Library, University of Texas at San Antonio, San Antonio, TX 78285.

\section{Law and Political Science Section (LPSS)}

Vice-Chair/Chair-Elect: Stephen J. Bensman, Social Sciences Bibliographer, Troy H. Middleton Library, Louisiana State University, Baton Rouge, LA 70803; Kathleen Gunning, Head of Reference and Information Services, University of Houston, Houston, TX 77004.

Member-at-Large (one-year term): Fred Blum, Reference Librarian, Eastern Michigan University Library, Ypsilanti, MI 48197; Natalie Schatz, Chief Documents Librarian, Harvard College Library, Cambridge, MA 02138.

\section{Rare Books and Manuscrupts Section (RBMS)}

Vice-Chair/Chair-Elect: Anna L. Ashby, Associate Curator of Printed Books, The Pierpont Morgan Library, 29 East 36th Street, New York, NY 10016; Marie E. Korey, Rare Book Librarian, Free Library of Philadelphia, Logan Square, Philadelphia, PA 19103.

Member-at-Large (three-year term): R. Russell Maylone, Curator, Special Collections Department, Northwestern University Library, Evanston, IL 60201; Robert Nikirk, Librarian, Grolier Club, 47 E. 60th Street, New York, NY 10022.

\section{Science and Technology Section (STS)}

Vice-Chair/Chair-Elect: John W. Beecher, Head of Public Services, St. Paul Campus Library, 1984 Buford Avenue, St. Paul, MN 55108; Eleanor Mathews, Reference Department, Iowa State University Library, Ames, IA 50011.

Secretary (one-year term): James E. Bobick, Head of Collection Development, Temple University, 211 Paley Library, Philadelphia, PA 19122; Marie Dvorzak, Head, Winchell Library of Geology, University of Minnesota, 204 Pillsbury Hall, Minneapolis, MN 55455.

Slavic and East European Section (SEES)

Vice-Chair/Chair-Elect: Wojciech Zalewski,
Curator for Russian and East European Collections, Stanford University Libraries, Stanford, CA 94305; Nadia Zilper, Slavic and East European Resources Bibliographer, The University of North Carolina at Chapel Hill, Wilson Library 024 A, Chapel Hill, NC 27514.

Secretary (three-year term): Leon Ferder, Slavic Bibliographer, University Research Library, University of California, Los Angeles, CA 90024; Robert Fitzgerald, Slavic Cataloger, Northwestern University Library, 1935 Sheridan Road, Evanston, IL 60201.

Member-at-Large (one-year term): Natalia Bezugloff, Head, Foreign Literature Department, Cleveland Public Library, 325 Superior Avenue, Cleveland, OH 44114; Edward Kasinec, Librarian for Slavic Collections, University of California, Berkeley Library, Room 346, Collection Development, Berkeley, CA 94720.

\section{University LibraRies SECTION (ULS)}

Vice-Chair/Chair-Elect: Patricia L. Bril, Chair, Reader Services Department, California State University, Fullerton, P.O. Box 4150, Fullerton, CA 92634; Shelley E. Phipps, Head Librarian, Science-Engineering Library, University of Arizona, Tucson, AZ 85721.

\section{Western European Specialists Section (WESS)}

Vice-Chair/Chair-Elect: James Campbell, North Europe Bibliographer, Alderman Library, University of Virginia, Charlottesville, VA 22907; John B. Dillon, Humanities Bibliographer, Glenn G. Bartle Library, SUNY-Binghamton, Binghamton, NY 13901.

Secretary (one-year term): C. Roger Davis, Bibliographer, Smith College Library, Northampton, MA 01063; Richard Bruce Warr, Humanities/History Bibliographer, Alexander Library, Rutgers University, New Brunswick, NJ 08903.

Member-at-Large (one-year term): Assunta Pisani, Specialist in Book Selection for French and Italian, Harvard College Library, Cambridge, MA 02138; Mariann Tiblin, Bibliographer, Scandinavian Area Studies, Wilson Library, University of Minnesota, 309 19th Avenue S., Minneapolis, MN 55445.

\section{New Budget \& Finance Chair}

Robert Almony, assistant director of the Ellis Library at the University of Missouri, Columbia, has been appointed by ACRL President Joyce Ball to serve as chair of the Budget and Finance Committee for the remainder of Sherrie Bergman's unexpired term. Bergman resigned in October to go on maternity leave, which will lead into an extended leave through June 1984 to do an indexing project for Wheaton College. 


\section{Attention...}

\section{Online users; Librarians who assist users of the PAIS indexes}

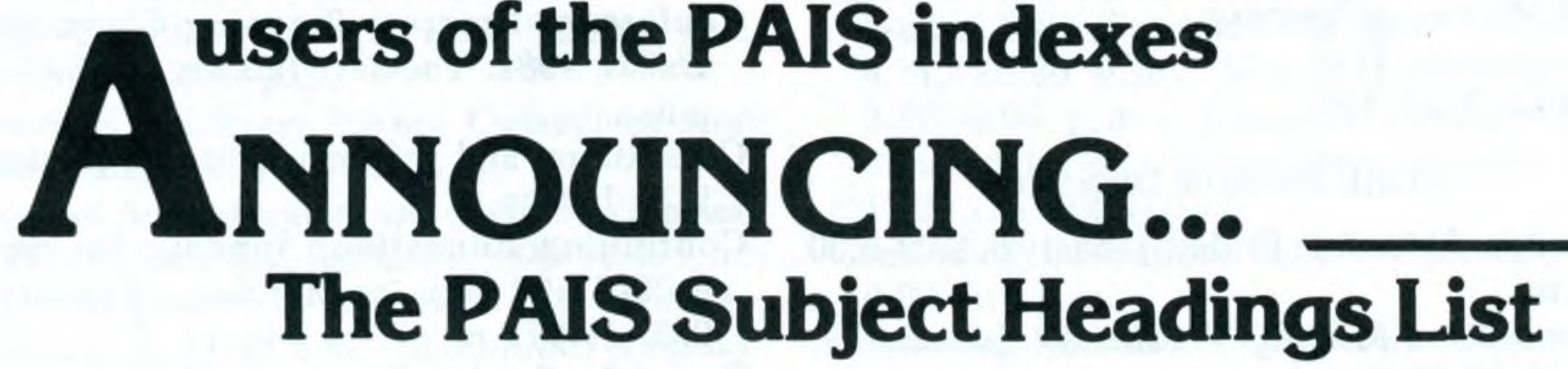

This substantial new reference tool will be an indispensable aid for users of both the PAIS printed indexes as well as the PAIS online database. PAIS utilizes a standardized, controlled vocabulary supplemented by an elaborate cross reference structure. Effective retrieval of PAIS information will be greatly enhanced through the use of The PAIS Subject Headings List, the guide to over 8,000 subject headings used in the indexes.

\section{Also included in the new guide are: * Scope notes-descriptions of those subject headings which require further explanation \\ * See and See also references \\ * See from and See also from references \\ * Subheadings list \\ * A user's guide - an introduction to the use of The PAIS Subject Headings List}

\section{Prepublication Offer:}

This important new publication is the culmination of years of preparation and countless hours of editorial effort. However, it is available at a prepublication price of just $\$ 37.50$ until December $31,1983$. (After that date the price will be $\$ 45$ for PAIS members and $\$ 55$ for nonmembers.) Use the order form below to reserve your copy at the prepublication price.

The PAIS Bulletin and its companion publication, the PAIS Foreign Language Index, cover the entire range of the social sciences with particular emphasis on public policy and issues in the public debate. PAIS covers economics, business and finance, government and public administration, demography, political science, international relations, law and legislation, and statistics. Those not familiar with PAIS services may use the order form below to request additional information on the comprehensive PAIS printed indexes and online database.

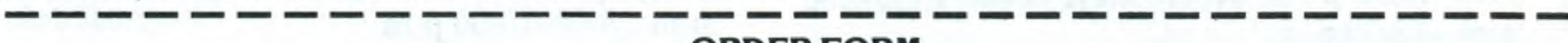
ORDER FORM

Please reserve my copy of The PAIS Subject Headings List at the prepublication price of $\$ 37.50$.

(I understand this offer is good until December 31,1983 .)

Name

Department

Library

Address

City State Zip

$\square$ Bill me $\quad \square$ Payment enclosed

Please send more information on:

AIS Bulletin

PAIS Foreign Language Index PAIS Database

\section{Public Affairs Information Service}

11 West 40 th Street

New York, N.Y. 10018

(212) $736-6629$ 